\title{
HUBUNGAN PENAMBAHAN BERAT BADAN PADA AKSEPTOR KONTRASEPSI HORMONAL DI BPM ZUNIAWATI PALEMBANG
}

\author{
Annisa Khoiriah \\ STIK Siti Khadijah Palembang \\ Email: annisakhr_1307@yahoo.co.id
}

\begin{abstract}
Abstrack: The Relations in Addition of Weight in Hormonal Contraception Acceptors at BPM Zuniawati Palembang. The use of hormonal contraception in a given period of time can cause various side effects one of which is the change in weight. The purpose of this study is to determine the relationship of weight gain on hormonal contraceptive acceptors. This study is an observational study by using secondary data from the Medical Record in BPM Zuniawati Palembang. The population in this research were 7,236 respondents and the sampling technique using Cross Sectional with Simple Random Sampling system with a sample of 99 respondents who use hormonal contraception. The data collection is done with the checklist. Based on the results of data analysis using Chi Square test showed that there is a relationship between weight gain with hormonal contraceptive acceptors ( $\mathrm{p}$-value $=0.001$ ). Respondents who experienced weight gain during the use of hormonal contraception by 66 respondents $(94.3 \%)$, while respondents who did not experience weight gain of five respondents (17.2\%).
\end{abstract}

Keywords: Weight gain, Hormonal contraceptive, Acceptors

\begin{abstract}
Abstrak: Hubungan Penambahan Berat Badan pada Akseptor Kontrasepsi Hormonal di BPM Zuniwati Palembang. Penggunaan alat kontrasepsi hormonal dalam jangka waktu tertentu dapat menimbulkan berbagai efek samping salah satunya adalah perubahan berat badan. Tujuan penelitian ini untuk mengetahui hubungan penambahan berat badan pada akseptor kontrasepsi hormonal. Penelitian ini merupakan penelitian observasi dengan menggunakan data sekunder dari Medical Record di BPM Zuniawati Palembang. Populasi dalam penelitian ini berjumlah 7.236 responden dan teknik pengambilan sampel ini menggunakan Cross Sectional dengan sistem Simple Random Sampling dengan jumlah sampel 99 responden yang menggunakan kontrasepsi hormonal. Pengumpulan data dilakukan dengan checklist. Berdasarkan hasil analisa data menggunakan uji Chi Square didapatkan bahwa ada hubungan antara penambahan berat badan dengan akseptor kontrasepsi hormonal ( $p$-value $=0,001)$. Responden yang mengalami penambahan berat badan selama menggunakan alat kontrasepsi hormonal sebesar 66 responden $(94,3 \%)$, sedangkan responden yang tidak mengalami penambahan berat badan sebesar 5 responden $(17,2 \%)$.
\end{abstract}

Kata kunci: Penambahan berat badan, Akseptor, Kontrasepsi hormonal

Dalam rangka mewujudkan penduduk tumbuh seimbang dan keluargaberkualitas, pemerintah menetapkan kebijakan keluarga berencana melalui penyelenggaraan program keluargaberencana. Keluarga Berencana (KB) adalah salah satu pelayanan kesehatan yang paling dasar dan utama bagi wanita, meskipun tidak selalu diakui demikian. Untuk optimalisasi manfaat kesehatan $\mathrm{KB}$, pelayanan tersebut harus disediakan bagi wanita dengan cara mengeluarkan dan memenuhi kebutuhan pelayanan kesehatan reproduksi. Banyak wanita yang harus menentukan pilihan kontrasepsi yang sulit, tidak hanya karena keterbatasan pengetahuan mereka tentang pilihan kontrasepsi, tetapi juga metode-metode tersebut mungkin tidak diterimah, sehubungan dengan kebijakan nasional KB. Dalam memilih suatu metode, wanita harus menimbang berbagai faktor, termasuk status kesehatan mereka, efek samping potensial suatu metode, konsekuensi terhadap kehamilan yang tidak diinginkan, besarnya keluarga yang diinginkan, kerja sama pasangan dan norma budaya mengenai kemampuan mempunyai anak (Maryani, 2003).

Pilihan kontrasepsi yang ada sekarang memungkinkan wanita atau pasangan untuk memilih kontrasepsi yang paling sesuai untuk keadaan khusus mereka sendiri. Saat ini wanita mempunyai lebih banyak pilihan kontrasepsi yang reversible atau sementara dari pada lakilaki. Wanita dapat memilih metode perintang (diafragma vagina, cervical cap, spon vagina, kondom vagina), kontrasepsi hormonal (pil, suntikan, implan), spiral (IUD) (Jones, 2001).

Penggunaan alat kontrasepsi hormonal dalam jangka waktu tertentu dapat menimbulkan berbagai efek samping salah satunya adalah 
perubahan berat badan. Namun demikian, berat badan yang bertambah umunya tidak terlalu besar, hal ini bervariasi antara kurang dari $1 \mathrm{~kg}$ sampai5 $\mathrm{kg}$ dalam tahun pertama. Sebagian besar wanita dari pasangan usia subur yang merupakan akseptor pengguna alat kontrasepsi mengalami peningkatan berat badan. Walaupun tingkat kelahiran dapat ditekan dalam mengatasl laju pertumbuhan penduduk, namun tidak dapat dihindari timbulnya dampak lain akibat penggunaan alat kontrasepsi khususnya penggunaan alat kontrasepsi hormonal dalam jangka waktu tertentu yang dapat menimbulkan berbagai efek samping, salah satunya adalah perubahan berat badan (Hartanto, 2004 dalam Maria, 2006).

Meskipun kontrasepsi hormonal menimbulkan berbagai dampak pada organ reproduksi maupun perubahan berat badan, namun kontrasepsi hormonal merupakan salah satu alat kontrasepsi yang penggunaannya meningkat dengan tajam. Menurut Word Health Organazation (WHO), dewasa ini hampir 380 juta pasangan di dunia menjalankan keluarga berencana dan 65-75 juta diantaranya terutama dinegeri berkembang menggunakan kontrasepsi hormonal seperti pil, suntik dan implan. Diperkirakan sekarang ini lebih dari 60 juta wanita di dunia menggunakan kontrasepsi oral dan lebih dari 10 juta menggunakan sediaan suntikan dan implan (Prawiroharjo, 2011).

Menurut World Health Organization menjelaskan bahwa terjadi peningkatan angka pengguna alat kontrasepsi terutama kontrasepsi yang mempunyai efektifitas jangka panjang yaitu implan tahun 2011 jumlah pengguna sebanyak 23,4\% meningkat pada tahun 2012 sebanyak 26,17\%. Menurut World Population Data Sheet tahun 2013, Indonesia merupakan negara ke-5 di dunia dengan estimasi jumlah penduduk terbanyak, yaitu 249 juta. Di antara negara ASEAN, Indonesia dengan luas wilayah terbesar tetap menjadi negara dengan penduduk terbanyak, jauh di atas 9 negara anggota lain. Dengan angka Fertilitas atau Total Fertility Rate (TFR) 2,6. Indonesia masih berada di atas ratarata TFR negara ASEAN yaitu 2,4 (WHO, 2013).

Berdasarkan data dari BPM Zuniawati Palembang tahun 2013 berjumlah 6.972 akseptor KB, 6.031 akseptor KB hormonal (Suntikan, Pil, dan Implan), 896 akseptor KB non hormonal (IUD dan Kondom). Dan dari bulan januari 2014 sampai dengan bulan april 2015 berjumlah 7.236 akseptor KB, akseptor yang menggunakan kontrasepsi hormonal berjumlah 6.182 (Suntikan, Pil dan Implan) dan akseptor kontrasepsi non hormonal berjumlah 1.054 (IUD dan Kondom).
Berdasarkan data yang diperoleh dari akseptor KB hormonal (Suntikan, Pil dan Implan) di BPM Zuniawati Palembang mengatakan bahwa kenaikan berat badan merupakan salah satu efek samping yang sering mereka keluhkan.

\section{METODE PENELITIAN}

Penelitian ini menggunakan metode survei analitik dengan pendekatan "Cross Sectional" yaitu dimana pengumpulan data dilakukan dalam waktu bersamaan. Artinya, setiap subjek penelitian hanya diobservasi sekali saja dan dilakukan terhadap status karakter atau variabel subjek pada saat pemeriksaan.

Populasi pada penelitian ini semua akseptor kontrasepsi yang tercatat dalam rekam medik (medical record) di BPM Zuniawati Palembang dari bulan januari 2014 sampai bulan april 2015 berjumlah 7.236 akseptor KB. Akseptor KB yang menggunakan kontrasepsi hormonal berjumlah 6.182 akseptor (Suntikan, Pil dan Implan) dan kontrasepsi non hormonal berjumlah 1.054 akseptor (IUD dan Kondom).

Sampel penelitian adalah keseluruhan objek yang diteliti atau dianggap mewakili seluruh populasi dengan kriteria inklusi adalah karakteristik sampel yang dapat dimasukkan atau layak untuk diteliti (Nursalam, 2009). Pengambilan sampel dalam penelitian ini yakni menggunakan "Cross Sectional" dengan sistem "Simple Random Sampling" yaitu setiap anggota populasi memiliki kesempatan yang sama untuk dipilih sebagai sampel.

Penelitian ini dilaksanakan di BPM Zuniawati Palembang Tahun 2016 dan Penelitian ini dilakukan pada tanggal 27 Mei - 3 Juni 2016.

\section{HASIL}

\section{A. ANALISIS UNIVARIAT}

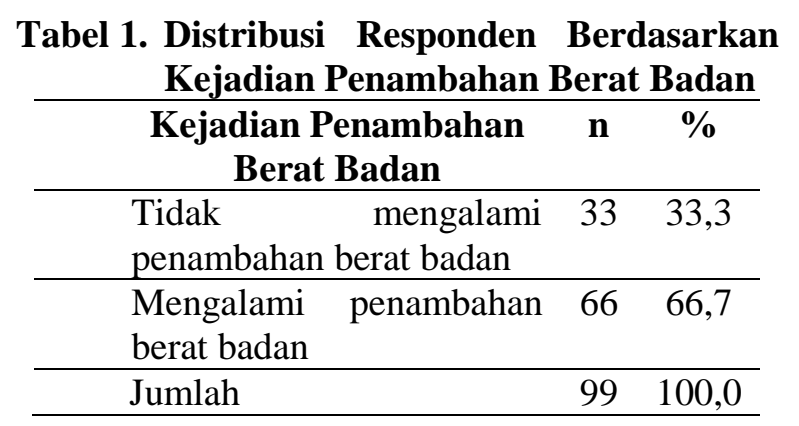

Penambahan berat badan diperoleh dari hasil pendataan pada responden mengenai data berat badan sebelum menggunakan kontrasepsi 
hormonal dan data berat badan setelah menggunakan kontrasepsi hormonal yang diperoleh dari hasil data sekunder.

Tabel 1 menunjukkan bahwa dari 99 responden, responden yang paling banyak mengalami peningkatan berat badan sebanyak 66 responden $(66.7 \%)$, daripada responden yang tidak mengalami penambahan berat badan sebanyak 33 respoden $(33.3 \%)$.

Akseptor kontrasepsi hormonal adalah salah satu yang digunakan akseptor sebagai alat kontrasepsi baik dalam bentuk pil, suntikan maupun implan yang diperoleh dari data sekunder.

\section{B. ANALISIS BIVARIAT}

Analisis bivariat pada penelitian ini bertujuan untuk melihat hubungan variabel dependen dan variabel independen. Seperti yang telah dijelaskan pada sebelumnya bahwa variabel dependen pada penelitian ini adalah akseptor kontrasepsi hormonal (pil, suntikan dan implan), sedangkan variabel independen yang diteliti
Tabel 2. Distribusi Responden Berdasarkan Jenis Kontrasepsi

Jenis Kontrasepsi

\begin{tabular}{lrrr}
$\begin{array}{l}\text { Tidak akseptor kontrasepsi } \\
\text { hormonal }\end{array}$ & 30 & 30,3 \\
\hline Akseptor kontrasepsi hormonal & 69 & 69,7 \\
\hline \multicolumn{2}{c}{ Jumlah } & 99 & 100,0 \\
\hline
\end{tabular}

Sumber: Kasiani, 2016

Tabel 2 menunjukkan bahwa dari 99 responden, jenis kontrasepsi yang paling banyak digunakan responden yaitu akseptor kontrasepsi hormonal (pil, suntik dan implan) sebesar 69 responden $(69,7 \%)$, sedangkan bukan akseptor kontrasepsi hormonal sebesar 30 responden $(30,3 \%)$.

dengan hubungannya dengan variabel dependen yaitu penambahan berat badan.

Hubungan penambahan berat badan pada akseptor kontrasepsi hormonal yaitu terjadinya penambahan berat yang dialami pada akseptor kontrasepsi hormonal.

Tabel 3. Hubungan Penambahan Berat Badan pada Akseptor Kontrasepsi Hormonal

\begin{tabular}{|c|c|c|c|c|c|c|c|c|}
\hline \multirow{3}{*}{$\begin{array}{l}\text { Penambahan } \\
\text { berat badan }\end{array}$} & \multicolumn{4}{|c|}{ Akseptor kontrasepsi hormonal } & \multirow{3}{*}{$\mathbf{n}$} & \multirow{3}{*}{$\%$} & \multirow{3}{*}{$p$-value } & \multirow{3}{*}{ OR } \\
\hline & \multicolumn{2}{|c|}{$\begin{array}{c}\text { Tidak Akseptor } \\
\text { Kontrasepsi } \\
\text { Hormonal }\end{array}$} & \multicolumn{2}{|c|}{$\begin{array}{c}\text { Akseptor } \\
\text { Kontrasepsi } \\
\text { Hormonal }\end{array}$} & & & & \\
\hline & n & $\%$ & n & $\%$ & & & & \\
\hline $\begin{array}{l}\text { Tidak } \\
\text { mengalami } \\
\text { penambahan } \\
\text { berat badan }\end{array}$ & 18 & 54.5 & 15 & 45.5 & 33 & 100,0 & $\rho=0,001$ & $\mathrm{OR}=5,400$ \\
\hline $\begin{array}{l}\text { Mengalami } \\
\text { penambahan } \\
\text { berat badan }\end{array}$ & 12 & 18.2 & 54 & 81.8 & 66 & 100,0 & & \\
\hline Jumlah & 30 & 30,3 & 69 & $69,7 \%$ & 99 & 100,0 & & \\
\hline
\end{tabular}

Sumber:Kasiani, 2016

Tabel 3 menunjukkan bahwa dari 66 responden yang mengalami penambahan berat badan lebih banyak pada akseptor kontrasepsi hormonal sebesar 54 responden $(81,8 \%)$, hal ini lebih besar dibandingkan dari 33 responden yang tidak mengalami penambahan berat badan pada akseptor kontrasepsi hormonal sebesar 15 responden $(45.5 \%)$.

Berdasarkan uji Chi-Square didapatkan nilai $p$-value $=0,001<\alpha=0,05$, dengan demikian Ho diterimah atau dapat disimpulkan bahwa "ada hubungan antara penambahan berat badan dengan akseptor kontrasepsi hormonal". Jika dilihat dari nilai OR 5.400 atau hubungan kuat, sehingga dapat dikatakan akseptor kontrasepsi hormonal memberikan kontribusi sebesar $5,4 \%$ terhadap penambahan berat badan.

\section{PEMBAHASAN}

Istilah kontrasepsi berasal dari kata kontra dan konsepsi. Kontra berarti "melawan" atau "mencegah", sedangkan konsepsi adalah pertemuan antara sel telur yang matang dengan sperma yang mengakibatkan kehamilan. Maksud dari kontrasepsi adalah menghindari atau mencegah terjadinya kehamilan sebagai akibat 
adanya pertemuan antara sel telur dengan sel sperma.Cara kerja kontrasepsi bermacam-macam, tetapi pada umumnya mempunyai fungsi mengusah akan agar tidak terjadi ovulasi, melumpuhkan sperma, serta menghalangi pertemuan sel telur dengan sperma.

Kontrasepsi hormonal merupakan salah satu metode kontrasepsi yang paling efektif dan reversibel untuk mencegah terjadinya konsepsi. Kebanyakan jenis hormon yang terkandung dalam kontrasepsi hormonal adalah jenis sintetik, kecuali yang terkandung dalam depo medroksiprogesteron (depo MPA), yang jenis hormonnya adalah progesteron alamiah (Baziad, 2002).

Hasil penelitian hubungan penambahan berat badan pada akseptor kontrasepsi hormonal di BPM Zuniawati Palembang Tahun 2015 dalam hal initentang terjadinya penambahan berat badan yang terjadi pada akseptor kontrasepsi hormonal (suntikan, pil dan implan).

Hasil penelitian menunjukkan bahwa penambahan berat badan terjadi pada akseptor kontrasepsi hormonal sebanyak 54 responden (81.8\%) yang mengalami penambahan berat badan, sedangkan yang tidak mengalami penambahan berat badan sebanyak 15 responden (45,5\%). Dan yang tidak akseptor kontrasepsi hormonal sebanyak 12 responden $(18,2 \%)$ yang mengalami penambahan berat badan, sedangkan yang tidak mengalami penambahan berat badan 18 responden $(54,5 \%)$.

Berdasarkan uji Chi-Square didapatkan nilai $p$-value $0,001<\alpha 0,05$, dengan demikian Ho diterimah atau dapat disimpulkan bahwa "ada hubungan antara penambahan berat badan dengan akseptor kontrasepsi hormonal". Jika dilihat dari nilai OR 5.400 atau hubungan kuat, sehingga dapat dikatakan akseptor kontrasepsi hormonal memberikan kontribusi sebesar $5,4 \%$ terhadap penambahan berat badan.

Penelitian ini sejalan dengan survei yang dilakukan oleh Darmawati, dkk (2012) yang berjudul hubungan penggunaan kontrasepsi hormonal dengan kenaikan berat badan pada akseptor kontrasepsi hormonal di Desa Batoh, menyatakan bahwa pada penggunaan pil oral sebagian besar wanita mengalami perubahan berat badan yang dikarenakan adanya retensi cairan dari progestin atau estrogen yang mengakibatkan bertambahnya lemak subkutan terutama pada pinggul, paha dan payudara. Peningkatan berat badan pada peserta Implan dapat diakibatkan efek dari kegagalan inhibiting kerja hipofise dalam mensekresi hormon yang menggakibatkan peningkatan nafsu makan. Sedangkan kontrasepsi Suntikan mengandung hormon estrogen dan progesteron dalam terapinya, sehingga terjadi peningkatan jumlah hormon progesteron dan estrogen didalam tubuh, sehingga terjadi nafsu makan akan bertambah dan berakibat makan lebih banyak. Pencapaian peserta KB baru di Provinsi Aceh secara keseluruhan berdasarkan uji statistic dengan $p$ value $=0,000$ yang berarti $<0,05$ ini menunjukkan Ho ditolak berdasarkan uji statistik, hal ini menunjukkan ada hubungan antara penggunaan kontrasepsi suntikkan dengan kenaikan berat badan pada akseptor kontrasepsi hormonal di Desa batoh kecamatan Lueng Bata. Dan berdasarkan uji statistik dengan Fisher's Exact Test, didapatkan bahwa nilai $p$-value $=0,0006$ yang berarti $p$-value $<0,05$ sehingga Ho ditolak dan $\mathrm{Ha}$ diterimah. Ini menunjukkan ada hubungan antara penggunaan kontrasepsi pil/implan dengan kenaikan berat badan pada akseptor kontrasepsi hormonal di Desa Batoh Kecamatan Lueng Bata.

Dan di dukung dari hasil penelitian Efi Sriwahyuni 2012 yang berjudul hubungan antara jenis dan lama pemakaian alat kontrasepsi hormonal dengan peningkatan berat badan akseptor di Surabaya. Pada penelitian ini didapatkan hasil bahwa respondenyang menggunakan alat kontrasepsi hormonal lebih darisatu tahun yang mengalami peningkatan berat badanadalah sebesar $85,7 \%$ dan berdasarkan uji chi-square dengan menggunakan tabel $2 \times 2$ diperoleh nilai $\rho$ sebesar 0,016 sehingga dapat disimpulkan bahwa ada hubunganantara lama penggunaan alat kontrasepsi hormonal yangdipakai responden terhadap peningkatan berat badan. Lama pemakaian alat kontrasepsi hormonal menunjukkan bahwa responden yang menggunakan alat kontrasepsi hormonal lebih dari satu tahun memiliki risiko sebesar 4,250 kali lebih besar mengalami peningkatan berat badan dibandingkan dengan responden yang menggunakan alat kontrasepsi hormonal tidak lebih dari satu tahun.Responden yang mengalami peningkatanberat badan selama menggunakan alat kontrasepsihormonal sebesar $66,7 \%$ sedangkan responden yang tidak mengalami peningkatan berat badan adalah sebesar 33,3\% responden.

Menurut Hartanto (2004), penggunaan alat kontrasepsi hormonal dalam jangka waktu tertentu dapat menimbulkan berbagai efek samping salah satunya adalah perubahan berat badan. Namun demikian, berat badan yang bertambah umumnya tidak terlalu besar, hal ini bervariasi antara kurang dari $1 \mathrm{~kg}$ sampai $5 \mathrm{~kg}$ dalam tahun pertama. Sebagian besar wanita dari pasangan usia subur yang merupakan akseptor 
pengguna alat kontrasepsi mengalami peningkatan berat badan. Pil merupakan jenis kontrasepsi yang mengalami peningkatan berat badan rata-rata $1-5 \mathrm{~kg}$ sedangkan suntikan dan implan rata-rata mengalami peningkatan berat badan sebesar 1-2 kg. Dan menurut Saifudin (2003), hal ini disebabkan karena kandungan dari hormon estrogen dan progesteron yang terdapat pada kontrasepsi pil, dimana hormon estrogen menyebabkan retensi cairan dan oedema, sedangkan progesterone mempermudah penumpukan karbohidrat dan gula menjadi lemak dan merangsang nafsu makan serta menurunkan aktifitas fisik, akibatnya pemakaian kontrasepsi hormonal dapat menyebabkan bertambah berat badan. Umumnya pertambahan berat badan tidak terlalu besar, untuk jenis kontrasepsi pil bervariasi antara 1-5 kg. Sedangkan jenis kontrasepsi suntikan dan implan biasanya terjadi kenaikan atau penurunan berat badan 1-2 kg.

Berdasarkan hasil penelitian dan teori yang ada maka peneliti berasumsi bahwa di BPM Zuniawati Palembang Tahun 2015 secara keseluruhan penggunaan kontrasepsi hormonal baik bentuk pil, suntikan maupun implan dapat mempengaruhi penambahan berat badan. Akseptor yang menggunakan kontrasepsi hormonal lebih cenderung/banyak mengalami penambahan berat badan sekitar 1-3 kg, sedangkan yang bukan akseptor kontrasepsi hormonal sedikit mengalami penambahan berat badan. Hal ini disebabkan karenakan kandungan hormon pada kontrasepsi hormonal yaitu hormon estrogen dan progesteron yang dapat merangsang pusat pengendali nafsu makan di hipotalamus yang menyebabkan akseptor makan lebih banyak dari biasanya. Dan rata-rata akseptor yang menggunakan kontrasepsi hormonal dipengaruhi faktor lain seperti kebiasaan pola makan atau asupan gizi dan aktivitas fisik yang dilakukan oleh akseptor maka penambahan berat badan akseptor lebih meningkat setelah menggunakan kontrasepsi hormonal. Maka akseptor kontrasepsi hormonal akan mengalami penambahan berat badan setelah penggunaan kontrasepsi hormonal dalam jangka waktu setelah kurang lebih 3 bulan pemakaian.

\section{Hubungan Penambahan Berat Badan pada Akseptor Kontrasepsi Hormonal}

Hasil penelitian menunjukkan bahwa penambahan berat badan terjadi pada akseptor kontrasepsi hormonal sebanyak 54 responden $(81,8 \%)$ yang mengalami penambahan berat badan, sedangkan yang tidak mengalami penambahan berat badan sebanyak 15 responden
(45,5\%). Dan yang tidak akseptor kontrasepsi hormonal sebanyak 12 responden $(18,2 \%)$ yang mengalami penambahan berat badan, sedangkan yang tidak mengalami penambahan berat badan 18 responden $(54,5 \%)$.

Berdasarkan uji Chi-Square didapatkan nilai $p$-value $=0.001<\alpha=0,05$, dengan demikian Ho diterimah atau dapat disimpulkan bahwa "ada hubungan antara penambahan berat badan dengan akseptor kontrasepsi hormonal". Jika dilihat dari nilai OR 5.400 atau hubungan kuat, sehingga dapat dikatakan akseptor kontrasepsi hormonal memberikan kontribusi sebesar $5,4 \%$ terhadap penambahan berat badan.

Penelitian ini sejalan dengan survei yang dilakukan oleh Darmawati, dkk (2012), menyatakan bahwa pada penggunaan pil oral sebagian besar wanita mengalami perubahan berat badan yang dikarenakan adanya retensi cairan dari progestin atau estrogen yang mengakibatkan bertambahnya lemak subkutan terutama pada pinggul, paha dan payudara. Peningkatan berat badan pada peserta Implan dapat diakibatkan efek dari kegagalan inhibiting kerja hipofise dalam mensekresi hormon yang menggakibatkan peningkatan nafsu makan. Sedangkan kontrasepsi Suntikan mengandung hormon estrogen dan progesteron dalam terapinya, sehingga terjadi peningkatan jumlah hormon progesteron dan estrogen didalam tubuh, sehingga terjadi nafsu makan akan bertambah dan berakibat makan lebih banyak.

Kontrasepsi hormonal merupakan salah satu metode kontrasepsi yang paling efektif dan reversibel untuk mencegah terjadinya konsepsi. Kebanyakan jenis hormon yang terkandung dalam kontrasepsi hormonal adalah jenis sintetik, kecuali yang terkandung dalam depo medroksiprogesteron (depo MPA), yang jenis hormonnya adalah progesteron alamiah (Baziad, 2002).

Menurut Hartanto (2004), penggunaan alat kontrasepsi hormonal dalam jangka waktu tertentu dapat menimbulkan berbagai efek samping salah satunya adalah perubahan berat badan. Namun demikian, berat badan yang bertambah umumnya tidak terlalu besar, hal ini bervariasi antara kurang dari $1 \mathrm{~kg}$ sampai $5 \mathrm{~kg}$ dalam tahun pertama. Sebagian besar wanita dari pasangan usia subur yang merupakan akseptor pengguna alat kontrasepsi mengalami peningkatan berat badan. Pil merupakan jenis kontrasepsi yang mengalami peningkatan berat badan rata-rata $1-5 \mathrm{~kg}$ sedangkan suntikan dan implan rata-rata mengalami peningkatan berat badan sebesar 1-2 kg. Dan menurut Saifudin (2003), hal ini disebabkan karena kandungan dari 
hormon estrogen dan progesteron yang terdapat pada kontrasepsi pil, dimana hormon estrogen menyebabkan retensi cairan dan oedema, sedangkan progesteron mempermudah penumpukan karbohidrat dan gula menjadi lemak dan merangsang nafsu makan serta menurunkan aktifitas fisik, akibatnya pemakaian kontrasepsi hormonal dapat menyebabkan bertambah berat badan. Umumnya pertambahan berat badan tidak terlalu besar, untuk jenis kontrasepsi pil bervariasi antara 1-5 kg. Sedangkan jenis kontrasepsi suntikan dan implan biasanya terjadi kenaikan atau penurunan berat badan $1-2 \mathrm{~kg}$.

Secara keseluruhan penggunaan kontrasepsi hormonal baik bentuk pil, suntikan maupun implan dapat mempengaruhi penambahan berat badan. Akseptor yang menggunakan kontrasepsi hormonal lebih cenderung/banyak mengalami penambahan berat badan sekitar 1-3 kg, sedangkan yang bukan akseptor kontrasepsi hormonal sedikit mengalami penambahan berat badan. Hal ini ditunjukkan dari hasil penelitian dan teori di BPM Zuniawati Palembang. Dan Hal ini disebabkan karenakan kandungan hormon pada kontrasepsi hormonal yaitu hormon estrogen dan progesteron yang dapat merangsang pusat pengendali nafsu makan di hipotalamus yang menyebabkan akseptor makan lebih banyak dari biasanya. Dan rata-rata akseptor yang menggunakan kontrasepsi hormonal dipengaruhi faktor lain seperti kebiasaan pola makan atau asupan gizi dan aktivitas fisik yang dilakukan oleh akseptor maka penambahan berat badan akseptor lebih meningkat setelah menggunakan kontrasepsi hormonal. Maka akseptor kontrasepsi hormonal akan mengalami penambahan berat badan setelah penggunaan kontrasepsi hormonal dalam jangka waktu setelah kurang lebih 3 bulan pemakaian.

\section{SIMPULAN}

Berdasarkan hasil penelitian dan pembahasan dapat disimpulkan bahwa Ada hubungan bermakna antara penambahan berat badan pada akseptor kontrasepsi hormonal di BPM Zuniawati Palembang dengan hasil uji statistik nilai $p$-value $=0,001<\alpha=0,05$, hipotesa awal terbukti secara statistik.

\section{SARAN}

Direkomendasikan bagi institusi pendidikan, pelayanan kesehatan agar dapat mengembangkan upaya promosi kesehatan dan meningkatkan pelayanan kesehatan khususnya pada ibu yang akan menggunakan alat kontrasepsi hormonal.

\section{DAFTAR PUSTAKA}

Baziad, A. 2002. Kontrasepsi Hormonal, Edisi 1. Jakarta: Yayasan Bina Pustaka.

BKKBN Nasional. 2013. Situasi dan Analisi Keluarga Berencana 2013. http://www.bkkbn.go.id/kependudukan/Pa ges/DataSurvey/SDKI/Kesertaan_KB/CPR /Nasional.aspx (Diakses 9 April 2016).

Darmawati, dkk. 2012. Hubungan Penggunaan Kontrasepsi Hormonal Dengan Kenaikkan Berat Badan Pada Akseptor Kontrasepsi hormonal Di Desa Batoh Tahun 2012. Jurnal PSIK-FK Universitas Syiah Kuala Banda Aceh. (Diakses 28 Maret 2016).

Hartanto, H. 2010. Keluarga Berencana dan Kontrasepsi. Jakarta: SinarHarapan.

Jones, L.D. 2001. Dasar-dasar Obstetri dan Ginekologi. Jakarta: Hipokrates.
Maryani, H. 2003. Cara Tepat Memilih Kontrasepsi Keluarga Berencana bagi Wanita. Jakarta: Depkes. RI.

Nursalam. 2009. Metode Penelitian Ilmu Keperawatan. Jakarta: Salemba Medika.

Sriwahyuni, Efi., dkk. 2012. Tentang Hubungan antara Jenis dan Lama Pemakaian Alat Kontrasepsi Hormonal dengan Peningkatan Berat Badan Akseptor. Jurnal Falkultas Kesehatan Masyarakat Universitas Airlangga Surabaya. (Diakses 7 April 2016).

Tukiman, Suryanti. 2012. Hubungan Penggunaan Kontrasepsi Hormonal Dengan Kejadian Peningkatan Berat Badan Pada Wanita Usia Subur Di Puskesmas Tamalanrea Makassar. Skripsi Sarjana. Fakultas Kesehatan Masyarakat Universitas Hasanudin Makassar. 